УДК: 371.214:81'243

\title{
A COMPARATIVE ANALYSIS OF FOREIGN LANGUAGE CURRICULA IN THE INDEPENDENT UKRAINE (FROM 1998 TO 2020)
}

\author{
Huszti I. \\ huszti@kmf.uz.ua \\ https://orcid.org/0000-0002-1900-8112 \\ Ferenc Rákóczi II Transcarpathian Hungarian College of Higher Education, Berehove \\ Paper received 18.05.2020. Accepted for publication 14.06.2020.
}

\begin{abstract}
A comparative analysis of foreign language curricula in the independent Ukraine (from 1998 to 2020)
Abstract. The present theoretical paper attempts to introduce, analyse, compare and contrast the foreign language curricula in use at various periods of time in the independent Ukraine between 1998 and 2020. The analysis mainly focuses on the foreign language curricula in Ukraine in general and the concentric structure of curricula in particular. Curricula applied in ordinary schools (not specialized ones) lie in the centre of attention of this investigation. The article presents the findings of document analysis as a research instrument.

Key words: foreign language curricula in Ukraine, CEFR levels, number of weekly hours in English, concentric and linear structures of curricula.
\end{abstract}

Густі I. I. Закарпатський угорський інститут ім. Ференца Ракоці II, Берегове Порівняльний аналіз навчальних програм з іноземних мов у незалежній Україні (3 1998 по 2020 рр.) Анотація. Bcmyn. Сьогодні в загальноосвітніх школах України викладають переважно чотири іноземні мови: англійську, німецьку, французьку й іспанську. Кількість шкіл у державі, які забезпечують навчання іноземних мов на базовому (середньому) рівні, більша порівняно з тими, де навчання іноземних мов забезпечено на підвищеному рівні. Це означає, що більшість шкіл у процесі навчання іноземних мов керується стандартною навчальною програмою, а не спеціалізованою. Мета. Наша мета - проаналізувати навчальні програми з англійської мови, які використовувалися і наразі використовуються у загальноосвітніх школах незалежної України для навчання іноземних мов. Методи. 3 метою порівняння різних навчальних програм було досліджено документи, які виконують функції регулювання навчання іноземних мов. Результати. Результати дослідження показали, що була певна схожість, але все ж таки переважали відмінності між навчальними програмами, які використовувалися в різні часи в Україні для навчання іноземних мов. По-перше, усі три досліджувані навчальні програми (1998, 2005 та 2018 років) містять змістові компоненти, які є обов'язковими для навчальних програм з іноземної мови, а саме: вимова, граматика, лексичний запас, прагматичні елементи, міжкультурні елементи, тексти, завдання, вправи та стратегії. Варто зазначити, що у всіх трьох навчальних програмах визначено цілі, яких мають досягти учні, проте лише найновіші навчальні програми орієнтуються на європейські стандарти, яких не віднайти у навчальній програмі 1998 року. У навчальних програмах 2005 та 2018 років вказано конкретні рівні володіння іноземною мовою, яких повинні досягати учні, а саме: рівень А1 в кінці початкової школи (4 клас), рівень А2 в кінці базової школи (9 клас) та рівень В1 при закінченні середньої школи (11 клас). Навчальна програма 2018 року дає чіткі вказівки щодо основних завдань процесу навчання іноземних мов у початковій школі України. Однак мовно-тематичний зміст, яким мають оволодіти учні в 1-4-их класах, замість цілеспрямованого й однозначного переліку всіх розмовних тем, у рамках яких повинні розмовляти учні, подається лише нечітким списком. Висновки. Необхідні подальші дослідження та зіставлення попередніх навчальних програм з іноземної мови із сучасними навчальними програмами "Нової української школи" для навчання іноземних мов у початкових та старших класах з метою виявлення їхніх недоліків й урахування пріоритетних дієвих новоуведень.

Ключові слова: навчальні програми з іноземних мов в Україні, рівні CEFR, кількість тижневих годин 3 англійської мови, концентричні та лінійні структури навчальних програм. 
Густи И. И. Закарпатский венгерский институт имени Ференца Ракоци II, Берегово Сравнительный анализ учебных программ по иностранному языку в независимой Украине (с 1998 по 2020 год)

Аннотация. В настоящей теоретической статье делается попытка описать, проанализировать, сравнить и сопоставить учебные программы по иностранному языку, используемые в различные периоды в независимой Украине между 1998 и 2020 гг. В основном анализ сосредоточен на учебных программах по иностранному языку в Украине в целом и в концентрической структуре учебных программ в частности. Учебные программы, применяемые в обычных (не специализированных) школах, находятся в центре внимания этого исследования. В статье представлены результаты анализа документов как инструмента исследования.

Ключевые слова: учебные планы по иностранному языку в Украине, уровни CEFR, количество часов в неделю по английскому языку, концентрические и линейные структуры учебных программ.

Introduction (problem statement). At present, there are four main foreign languages (FL) taught in state schools in Ukraine: English, German, French and Spanish. They are taught in two major contexts: in schools with general study of FL and in schools with advanced study of FL. This means that the schools in the first context follow a general curriculum of FL, while the schools in the second context use an in-depth curriculum of FL, with a higher number of weekly hours of FL than in the schools in the first context. Table 1 presents the present state of weekly hours in schools with general and advanced study of FL.

Table 1

Number of weekly hours of FL in different types of schools

\begin{tabular}{|c|c|c|}
\hline Class/Form & GFLCS & AFLCS \\
\hline 1 & 2 & 3 \\
\hline 2 & 2 & 4 \\
\hline 3 & 2 & 4 \\
\hline 4 & 2 & 4 \\
\hline 5 & 3 & 6 \\
\hline 6 & 3 & 6 \\
\hline 7 & 3 & 6 \\
\hline 8 & 3 & 6 \\
\hline 9 & 2 & 5.5 \\
\hline 10 & 3.5 & 5 \\
\hline 11 & 3.5 & 5 \\
\hline
\end{tabular}

(GFLCS = general foreign language curriculum school;

AFLCS $=$ advanced foreign language curriculum school)

After the collapse of the Soviet Union in 1991, independent states were created where the education system still used the curricula that were applied before. The new Ukrainian foreign language curriculum was issued by the Ministry of Education and Science of Ukraine in 1998. In the 2003/ 2004 academic year the teaching of a foreign language in Ukraine was introduced in Class 2, which fact necessitated the updating of the valid foreign language curriculum. As a result, a new document was published in 2005, which was based on European standards. Furthermore, unlike the previous foreign language curricula, it set the levels that children had to achieve in foreign languages during their primary and secondary level studies. Everything was in accordance with the standards described in the Common European Framework of Reference for Languages (CEFR, 2001). (See Table 2) 
Levels of knowledge to be achieved by learners at the end of certain school stages (source: Nikolayeva et al., 2013, p. 88)

\begin{tabular}{|c|c|c|c|c|}
\hline \multirow[b]{2}{*}{ School stage } & \multirow[b]{2}{*}{ Beginner } & \multirow[b]{2}{*}{ Basic / primary } & \multicolumn{2}{|c|}{ Upper / secondary } \\
\hline & & & $\begin{array}{c}\text { non-philological } \\
\text { specialization }\end{array}$ & $\begin{array}{c}\text { philological } \\
\text { specialization }\end{array}$ \\
\hline Class & 4. & 9. & 11. & 11. \\
\hline \multirow{2}{*}{$\begin{array}{l}\text { Level of language } \\
\text { knowledge }\end{array}$} & $\mathrm{A} 1$ & A2 & B1 & B2 \\
\hline & Breakthrough & Waystage & Threshold & Vantage \\
\hline
\end{tabular}

It is crucial to note that besides the different numbers of weekly hours in the two contexts, the content of teaching also differs. Therefore, two distinct curricula are in use in the schools. Because the first context of schools is significantly broader than the second one, i.e. GFLCSs are widespread and there are more of them than of AFLCSs, the object of investigation in this study is the foreign language curriculum applied in GFLCSs in Ukraine.

The analysis of recent research and publications.In the present article, the construct of curriculum is understood as what Dubin and Olshtain point out in their definition: "The term 'curriculum' $[$ is] used [...] to describe the broadest possible context in which planning for language instruction takes place" (Dubin \& Olshtain, 1986, p. 3). Berardo's view is also shared, who claims that a curriculum

... helps think systematically and coherently about how and what is being taught. It also highlights the learning principles involved in language learning as well as the learning strategies that students use. It helps create the best possible conditions for students to learn successfully as well as adopt the best pedagogic strategies to bring about successful learning outcomes (Berardo, 2007, p. 7).

Currently, compulsory public education in Ukraine is realized according to the Ukrainian Education Law (Law on Education of Ukraine, 2017) and takes place on three levels: 1st level or elementary school (Classes 1-4), 2nd level or primary school (Forms 5-9), 3rd upper level or secondary school (Forms 10-11) (Nikolayeva, Bihych, Borysko, and Boretska, 2013). Foreign language education is compulsory at all three levels: it starts in Class 1 and ends in Form 11. Elementary school (Classes 1-4) includes the first level, primary school (Forms 1-9) the first and second levels, and high school (Forms 1-11) all three levels.

The content of education refers to the totality of all the body of knowledge that a learner must acquire in the process of education. This ensures that the main goal of education is achieved, i.e. to teach students to communicate in a foreign language in typical intercultural situations within the framework of the acquired curriculum material. According to Nikolayeva (2010), the components of the content of education can be characterized in two aspects: objective and procedural.

The objective aspect includes: contexts and types of conversation, psychological and linguistic situations and roles, non-verbal means of communication, communicative goals and intentions. Shchukin (2007) describes the conversational context as a complex of interrelated conversational situations and topics defined by the needs of learners.In accordance with the foreign language curriculum in force today, students must be able to realize their communication intentions in the following conversational contexts: personal, public, and educational. In the secondary school, the professionally oriented context also belongs here. Regarding the types of conversation, we distinguish between oral and written communication, communication in the form of dialogue and monologue, private and formal, free and stereotypical communication, and so on. The main components of the procedural aspect of the content of education are language skills (listening, speaking, reading, and writing). 
Kurtán (2001) lists all the content components that should be included in any foreign language curriculum. These are the following:

1) Pronunciation

2) Grammar

3) Vocabulary

4) Pragmatic elements

5) Intercultural elements

6) Texts

7) Activities

8) Tasks

9) Strategies

It can be stated, as we will see later in the detailed analysis of the curricula that these components are included in the current Ukrainian foreign language curriculum, so the components listed by Kurtán (2001) are also true for the Ukrainian context.

The purpose of the studyis to introduce the results of document analysis (in this case analysis of FL curricula) with the aim of describing the foreign language curriculum currently in use in Ukraine and outlining, within the framework of a brief historical overview, where foreign language education started and where it came to in terms of documented foundations.

The results of the study. Foreign languages - English, German, French, Spanish: Curricula for Forms 5-11 (1998) was an official document of the Ministry of Education and Science of Ukraine that set out the goals that students had to achieve in secondary foreign language education. The curriculum included a list of conversational topics, grammatical structures, and language skills that students had to acquire. The structure of the curriculum was concentric (Kurtán 2001). This meant that the teaching content was broken down into smaller units taught at all levels of language teaching from beginner to secondary school, with the difference that when a topic was discussed at a higher level of knowledge, the material to be learnt was always more complex. One of the positive features of this way of arranging the language content was that students had the opportunity to practise a certain language phenomenon more than once, which led to a more precise fixation of the material. On the other hand, the recurrence of topics from time to time could also be demotivating for students (Kurtán 2001). The arrangement of language content in this way is similar to a spiral arrangement in which communicative functions and semantic units of language are built around grammatical structures. Such an arrangement of the content of language teaching allowed teachers to deal with vocabulary and grammar at the same time, as if they were moving higher and higher on the bend of a spiral. The advantage of the spiral arrangement of language content in the curriculum is that it is based on communicative language functions, so it is possible to practise different grammatical structures together with language functions. The most significant drawback, however, is that "in such an arrangement it is difficult to recognize grammar" (O’Neill 1972, quoted by Kurton, 2001, p. 116).

Foreign languages - English, German, French, Spanish: Curricula for Forms 5-11 (1998) consisted of three major parts. The first part contained the topics that the students had to master for oral use. The topics were grouped into three main themes, which occurred again and again each schoolyear, while the sub-themes varied from year to year. The three main themes were: 1 . The language learner and his environment, 2. Ukraine, 3 . The country or countries whose language the learner is learning.

The second part of the curriculum listed the language proficiency requirements for learners including those related to language functions. A separate list of requirements was given in the curriculum for each form from 5 to 11 .

The third part of the curriculum contained the language content to be acquired: phonetic knowledge was provided only for Form 5 in the curriculum, while vocabulary and grammar requirements were provided for all forms from 5 to 11. Interestingly, all the phonetic features of the English language 
had to be learned in Form 5 (at that time it was the first year of language learning). Although the nature of the curriculum was concentric, none of the later levels formally returned to the study of phenomena such as the pronunciation of short and long vowels or diphthongs, word and sentence stress, or the correct pronunciation of simple sentences.

The curriculum did not adapt to the standards described in the Common European Framework of Reference (CEFR, 2001) for the simple reason that it is earlier in chronological order than the CEFR. Apart from the lexical and grammatical material and the requirements for language skills, the curriculum did not mention any competencies (e.g. socio-cultural or strategic) that learners should have acquired. Nor was there any indication of the level of language proficiency learners had to achieve at the end of their studies.

As early as 2001, the position of the Ministry of Education and Science of Ukraine in the Official Gazette stated that foreign language education in Ukraine needed to be reformed (About the new foreign language curriculum, 2001, p. 15). The result was a new, revised curriculum. The growing need for communication and cooperation between foreign countries and Ukraine has led to significant changes in the field of foreign language education in primary and secondary schools. Changes in Ukrainian society and advances in the theory and practice of foreign language teaching have led the Ukrainian school to modernize the content and methods of foreign language teaching. Therefore, professionals have developed a new curriculum based on European standards, taking into account the recommendations of the Council of Europe (CEFR, 2001) on the teaching of foreign languages.

The two foreign language curricula in force today (Foreign languages - English, German, French, Spanish: Curricula for Forms 2-12,2005; Shyian, 2018) are significantly different from the previous ones, as they already rely on CEFR in all respects. (We are talking about two current curricula because the first is used in classes that started learning a foreign language in Ukraine before 2018, and the second from 2018, when they started teaching according to the New Ukrainian School concept.) The most striking difference compared to the previous curriculum is the fact that the curricula in force today specify the level of language proficiency that students must achieve during their schooling (see Table 2).

The curriculum requires that by the end of Form 9, students should be able to:

- have an oral discussion on topics related to the themes defined by the current curriculum;

- understand the content of the authentic texts by listening;

- understand the content of authentic reading texts of different genres and types;

- communicate in a written form according to the defined tasks;

- make appropriate use of the experience gained in the study of the mother tongue and other subjects, as a means of consciously acquiring a foreign language;

- use non-verbal means of communication if necessary, in case different language tools are not available to learners;

- critically evaluate information and use it to meet different needs;

- express their own thoughts, emotions and attitudes;

- collaborate effectively with others orally, in writing, and using electronic means of communication;

- select and apply appropriate communication strategies to meet different needs.

In the 2005 Curriculum, the sphere of conversation is divided into three parts, like in the previous one, which are repeated from year to year in each class, but the categories have changed: 1. personal, 2. public, and 3. educational. These categories are also repeated every year, but different conversational subtopics occur with different vocabulary.

The various language functions, the language structures to be learned and the vocabulary appear in the curriculum in a form of enumeration. While it was previously detailed what language (phonetics, grammar, vocabulary) and socio-cultural competencies learners had to acquire, in the current curriculum it all appears 'in bulk', which makes the work of teachers significantly more difficult, as in our opinion the transparency of the curriculum has deteriorated. 
In the current curriculum, it is already stipulated what should be taken into account when assessing learners' language skills, and what the scope of the texts created orally or in writing by the learners should be (see Table 3).

Guidelines for evaluation of oral and written performance of learners of Forms 5-9 (source: Foreign languages ..., 2005)

\begin{tabular}{|l|c|c|c|c|c|}
\hline \multirow{2}{*}{ Skill } & \multicolumn{5}{|c|}{ Form } \\
\cline { 2 - 6 } & 5 & 6 & 7 & 8 & 9 \\
\hline \multirow{2}{*}{$\begin{array}{l}\text { Auditory perception } \\
\text { (listening) }\end{array}$} & Length of listening text heard from the audio recording \\
\cline { 2 - 6 } & $\begin{array}{c}2-3 \\
\text { minutes }\end{array}$ & $\begin{array}{c}2-3 \\
\text { minutes }\end{array}$ & $\begin{array}{c}3-4 \\
\text { minutes }\end{array}$ & $\begin{array}{c}3-4 \\
\text { minutes }\end{array}$ & $\begin{array}{c}3-4 \\
\text { minutes }\end{array}$ \\
\hline $\begin{array}{l}\text { Visual perception } \\
\text { (reading, per minute) }\end{array}$ & \multicolumn{5}{|c|}{ Length of printed text (in characters) } \\
\cline { 2 - 6 } Oral perception (dialogue) & 500 & 600 & 700 & 800 & 900 \\
\hline \multirow{2}{*}{ Oral text creation (monologue) } & \multicolumn{7}{|c|}{ Number of correctly worded statements (per student) } \\
\cline { 2 - 6 } & 6 & 7 & 8 & 9 & 10 \\
\cline { 2 - 6 } & 10 & \multicolumn{5}{|c|}{$\begin{array}{l}\text { Length of written text (in words) } \\
\text { Written text creation (writing) }\end{array}$} & $80-90$ & $90-100$ & $100-110$ & $110-130$ & $130-150$ \\
\cline { 2 - 6 }
\end{tabular}

The curriculum describes the language competences that learners have to acquire by the end of the secondary school, i.e. Form 11 (at B1 level). This is summarized in Table 4.

\section{Language competences of secondary school learners - level B1} (source: Foreign languages ..., 2005)

\begin{tabular}{|l|l|}
\hline $\begin{array}{c}\text { Language } \\
\text { competence }\end{array}$ & \multicolumn{1}{|c|}{ Foreign language in the secondary school-level B1 } \\
\hline General & $\begin{array}{l}\text { The learner has the appropriate language skills, the appropriate vocabulary to talk } \\
\text { about topics such as family, hobbies and interests, travel, the latest news. Limited } \\
\text { vocabulary can lead to hesitation, indecision, repetition, and sometimes difficulty } \\
\text { in articulating one's ideas. }\end{array}$ \\
\hline Lexical & $\begin{array}{l}\text { The learner has sufficient vocabulary to talk without hesitation about everyday } \\
\text { topics: family, hobbies and interests, learning, travelling, the latest news. }\end{array}$ \\
\hline Grammatical & The learner applies common structures fairly well in predictable situations. \\
\hline Phonological & $\begin{array}{l}\text { The pronunciation of the learner is comprehensible overall, it is appropriate } \\
\text { at both sentence and word levels. }\end{array}$ \\
\hline
\end{tabular}

The curriculum also presents the criteria of evaluation of secondary school learners' performance. All of them are summarized in Table 5.

Guidelines for evaluation of oral and written performance of learners of Forms 10-11 (source: Foreign languages ..., 2005)

\begin{tabular}{|c|c|c|}
\hline \multirow[t]{2}{*}{ Skill } & \multicolumn{2}{|c|}{ Form } \\
\hline & 10 & 11 \\
\hline \multirow{2}{*}{ Auditory perception (listening) } & \multicolumn{2}{|c|}{ Length of listening text heard from the audio recording } \\
\hline & 3-4 minutes & 3-4 minutes \\
\hline \multirow[t]{2}{*}{ Visual perception (reading) } & \multicolumn{2}{|c|}{ Length of printed text (in words) } \\
\hline & $350-400$ & $400-450$ \\
\hline
\end{tabular}


If the primary school guidelines (Forms 5-9) (see Table 3) are compared to the secondary school guidelines (Forms 10-11) (see Table 5) concerning the evaluation of oral and written performance of learners, some oddities emerge.

1) Concerning auditory perception, the length of listening text heard from the audio recording is the same in Forms 7-9 and Forms 10-11 (3-4 minutes), although extra performance could already be expected in secondary school.

2) The requirements of visual perception (reading skill) cannot be compared because for the primary school (Table 3) text length is given in characters, while for the secondary school (Table 5) it is given in words.

3) In terms of oral interaction (dialogue), there is also a 'decline' compared to primary school, because while in Form 9 a learner has to make ten correctly worded statements during a dialogue, in Forms 10-11 only nine sentences are sufficient.

4) There is a huge decline in oral text creation (monologue). While in Form 9 the length of the text created should be 18 sentences, in Forms 10-11this quantity is only 13-14 sentences. Of course, it can also lead to misunderstandings that the parameters are given here in sentences, which is a broader concept than the number of specific words.

5) Only the last parameter can give some satisfaction because the principle of consistency is observed here. In the final year of primary school (Form 9), the text to be written should be at least 130-150 words, in Form 10 it is expected to be 150-180 words, and in Form 11, altogether 180-200 words.

However, a shortcoming is that the current curriculum does not contain any requirements or recommendations as to what assessment criteria learners must meet to be evaluated on the twelvepoint assessment scale used today in Ukraine to assess learners' knowledge. That is, although the data in Tables 3 and 5 were given as guideline assessment parameters, it is not clear what mark a learner who has completed these requirements deserves.

On 12 February 2018, the Ukrainian Parliament adopted the typical curriculum of the primary school edited by Shyian (2018), which defines:

- the total training load of learners and the expected learning outcomes;

- a list of educational sectors and their proposed content;

- the recommended forms of organization of the educational process and the tools of the internal quality assurance system of education.

The educational field of language and literature in the program edited by Shyian (2018) in relation to foreign language (English, German, French, and Spanish) teaching includes the following:

1) The foreign language teachingcurriculum was established on the basis of the state standard of primary education.

2) The aim of general secondary foreign language education is to develop the foreign language communication competence of direct and indirect intercultural communication, which ensures the development of other key competences and the satisfaction of the child's various life needs.

3) In accordance with the set goal, the main tasks of foreign language teaching in primary school are the following:

- realization of communication in the areas, topics and situations identified by the program;

- comprehension of the content of authentic audio texts via listening;

- reading comprehension of different types and genres of authentic texts;

- written communication in accordance with the set tasks;

- appropriate use of knowledge and experience gained during the study of the mother tongue and other subjects;

- critical evaluation of information and its use for various needs and purposes;

- expressing one's own thoughts, feelings and attitudes; 
- effective collaboration with others through verbal, written and electronic communication;

- selecting and applying appropriate communication strategies according to different needs;

- effective use of educational strategies for independent learning of foreign languages

4) By the end of Class 2, children in general educational institutions will reach the Pre-A1 level, and by the end of Class 4, the A1 level. These levels characterize the learning outcomes of each language activity and are in line with the guidelines of the Common European Framework of Reference (CEFR 2001).

5) According to the purpose of foreign language teaching and primary school tasks, the following content lines are distinguished: "Speech comprehension" or "Listening", "Visual perception" or "Reading comprehension", "Oral interaction", "Oral expression" or "Speaking", "Written interaction", "Written Expression", and "Online Interaction". The result of processing the latter content line is the ability of children to make basic connections using the simplest polite forms of greetings and farewells and to express simple statements about themselves online.

Table 6 summarizes the language content provided by the curriculum to be acquired by children in foreign language lessons.

Language content to be acquired in Classes 1-4 (source: Shyian, 2018)

\begin{tabular}{|c|c|c|}
\hline $\begin{array}{l}\text { Situational communication } \\
\text { topics and lexical range }\end{array}$ & Speech functions & $\begin{array}{l}\text { Linguistic content: grammar } \\
\text { and vocabulary }\end{array}$ \\
\hline $\begin{array}{l}\text { - Me, my family and friends } \\
\text { (family members, numbers up } \\
\text { to } 20 \text {, age of younger family } \\
\text { members and friends, daily } \\
\text { chores). } \\
\text { - Leisure (colours, games, } \\
\text { activities, days of the week, } \\
\text { walking, hobbies). } \\
\text { - Nature (pets, seasons, wild } \\
\text { and domestic animals). } \\
\text { Holidays and traditions in } \\
\text { Ukraine and the country of } \\
\text { the language learned (holidays, } \\
\text { greetings, birthdays, time } \\
\text { (telling the time), festive menu). } \\
\text { Man (body parts, clothing). } \\
\text { Food (simple menu, fruits, } \\
\text { vegetables, drinks, price). } \\
\text { School (school supplies, school } \\
\text { furniture, the classroom). }\end{array}$ & $\begin{array}{l}\text { - greeting, farewell, } \\
\text { apology, expressing } \\
\text { thanks, introduction, } \\
\text { personal description, } \\
\text { asking and answering } \\
\text { questions, understanding } \\
\text { and following simple } \\
\text { instructions, understanding } \\
\text { simple information boards, } \\
\text { festive greetings, } \\
\text { expressing the mood of } \\
\text { the holidays. }\end{array}$ & $\begin{array}{l}\text { The selection of the } \\
\text { communication situation is } \\
\text { based on the needs of the } \\
\text { learners and the principle of } \\
\text { concentric learning. It is not } \\
\text { a learning goal, so it is not } \\
\text { divided into separate lexical } \\
\text { or grammatical topics, but } \\
\text { should be mastered in the } \\
\text { context of communication } \\
\text { within a given situation. } \\
\text { The study of grammatical } \\
\text { material takes place primarily } \\
\text { at the level of lexical units: } \\
\text { children learn some } \\
\text { grammatical phenomena from } \\
\text { speech patterns without } \\
\text { explaining the morphological } \\
\text { and syntactic characteristics of } \\
\text { the linguistic units. }\end{array}$ \\
\hline
\end{tabular}

As a result of the document analysis, the following similarities and differences between the foreign language curricula used in Ukraine between 1998 and 2020 have been pointed out.

Similarities:

1. Both the 1998 and the 2005 curricula define clearly what objectives the learners have to achieve during their foreign language studies.

2. Both the 1998 and the 2005 curricula contain a list of conversational topics, grammatical structures, and language skills for learners to acquire.

3. Inboththe 1998 and the 2005 curricula, the sphere of conversation is divided in three parts. 
Differences:

1. The 1998 curriculum is not based on European standards (CEFR, 2001), whereas the 2005 curriculum is.

2. The 2005 curriculum specifies the level of language proficiency that students must achieve during their schooling. This specification is not present in the previous curriculum.

3. The structure of the 1998 curriculum was concentric (see Section 2.1), and the 2005 one is linear, in which the content units are built on each other from the simple to the complex.

4. The spheres of conversation cover various categories. In the 1998 curriculum, these were the language learner and his environment, Ukraine, andthe country or countries whose language the learner is learning; while in the 2005 curriculum the focus was a little different: personal, public, and educational themes.

5. The 1998 curriculum detailed what language content (phonetics, grammar, vocabulary) and socio-cultural competencies learners had to acquire. On the contrary, they are not described in detail in the 2005 curriculum, but are presented in the form of enumeration.

6. A major difference between the two curricula is that the 1998 one did not present any information about the evaluation of learners' knowledge, while the 2005 curriculum gives guidance as to how to evaluate children's oral and written performance.

Conclusion and prospects for further research.The Soviet Union collapsed and stopped existing in 1991. All its member states became independent countries, Ukraine included. However, the education system in this country continued functioning based on former curricula. A new foreign language curriculum was created in 1998 that was in force till the revised and renewed curriculum was published in 2005. The most significant and crucial difference between them was that the latter was based on European standards, taking into account the language proficiency levels advocated by the official document of the European Union related to language learning issues (CEFR, 2001). The curriculum clearly defines the levels that learners have to achieve at various stages of the school from Pre-A1 to B2. Such a requirement was not present in the 1998 curriculum.

The document analysis also revealed that the structure of the 1998 curriculum was concentric meaning that the topics that had to be covered reoccurred in further classes with a wider scope of the material. The benefit was that children had the opportunity to review themes annually, and thus widen and enrich their knowledge of a certain topic. On the other hand, the 2005 curriculum was linear in structure, meaning that the content units in it are built on one another starting from the simpler topics and advancing towards the more complex ones. The content units thus form a straight line along which the material can be taught.

Further research is needed to investigate the type of curricula in Ukraine that could be the focus of a future analysis. In addition, it will be worth studying the curriculum of the New Ukrainian School in relation to foreign languages in the upper primary and secondary forms.

\section{LITERATURE}

Закон України “Про освіту” (2017). Режим доступу: http://osvita.ua/legislation/law/2231/

Іноземні мови - англійська, німецька, франџузька, іспанська. Навчальні програми для 5-11 класів. (1998). Київ: Міністерство освіти і науки України.

Іноземні мови - англійська, німецька, французька, іспанська. Навчальні програми для 2-12 класів. (2005). Київ: Міністерство освіти і науки України.

Ніколаєва, С. Ю. (2010). Зміст навчання іноземних мов і культур у середніх навчальних закладах. Іноземні мови, 16(3), 3-11.

Ніколаєва, С. Ю., Бігич О. Б., Бориско Н. Ф., Борецька Г. Е. (2013). Методика навчання іноземних мов і культур: Теорія і практика. Київ: Ленвіт.

Про нову навчальну програму з іноземних мов. (2001). Інформаційний збірник Міністерства освіти і науки України, 9, 15-18. 
Шиян, Р. Б. (Ред.) (2018). Нова українська школа. Типова освітня програма для закладів загальної середньої освіти (1-4 клас). Режим доступу: https://osvita.ua/school/program/ program-1-4/60408/.

Щукин, А. Н. (2007). Лингводидактический энциклопедический словарь более 2000 единиц. Москва: Астрель.

Berardo, S. A. (2007). Designing a languagelearningsyllabus. Rome: ARACNE.

CEFR - Common European Framework of Reference for Languages: Learning, Teaching, Assessment. (2001). Cambridge: Cambridge University Press.

Dubin, F., \&Olshtain, E. (1986). Course design: developing programs and materials for language learning. Cambridge: Cambridge University Press.

Kurtán, Zs. (2001). Foreign language curricula. Budapest: National TextbookPublishers. / Kurtán, Zs. (2001). Idegen nyelvi tantervek. Budapest: Nemzeti Tankönyvkiadó.

O’Neill, R. (1972). Kernel lessons. London: Longman.

\section{REFERENCES}

Zakon Ukrajiny “Pro Osvitu”. (2017). Rezhymdostupu: http://osvita.ua/legislation/law/2231/

Inozemni movy - anhlijs'ka, nimets'ka, frantsuz'ka, ispans'ka. Navchal'ni prohramydlia 5-11 klasiv. (1998). Kyiv: Ministerstvo osvity i nauky Ukrajiny.

Inozemni movy - anhlijs'ka, nimets'ka, frantsuz'ka, ispans'ka. Navchal'ni prohramydlia 2-12 klasiv. (2005). Kyiv: Ministerstvo osvity i nauky Ukrajiny.

Nikolayeva, S. Yu. (2010). Zmist navchiannia inozemnyh mov i kul'tur u serednih navchal'nyh zakladah. InInozemni movy, 16(3), 3-11.

Nikolayeva S. Yu., Bihych O. B., Borysko N. F., \& Boretska, G. E. (2013). Metodyka navchiannia inozemnyh mov i kul'tur: Teoriya i praktyka. Kyiv: Lenvit.

Pro novunavchal'nu prohramu z inozemnyh mov. (2001). InInformatsiynyy zbirnyk Ministerstva osvity i nauky Ukrayiny, 9, str. 15-18.

Shyian, R. B. (Red.) (2018). Nova ukrajinska shkola. Typova osvitnia prohrama dlia zakladiv zahal'noji serednioji osvity (1-4 klas). Rezhym dostupu https:/osvita.ua/school/program/ program-1-4/60408/

Shchukin, A. N. (2007). Lingvodidakticheskiy entsyklopedicheskiy slovar' boleye 2000 yedinits. Moskva: Astrel'.

Berardo, S. A. (2007). Designing a language learning syllabus. Rome: ARACNE.

CEFR - Common European Framework of Reference for Languages: Learning, Teaching, Assessment. (2001). Cambridge: Cambridge University Press.

Dubin, F., \& Olshtain, E. (1986). Course design: developing programs and materials for language learning. Cambridge: Cambridge University Press.

Kurtán, Zs. (2001). Foreign language curricula. Budapest: National Textbook Publishers. / Kurtán, Zs. (2001). Idegen nyelvi tantervek. Budapest: Nemzeti Tankönyvkiadó.

O’Neill, R. (1972). Kernel lessons. London: Longman. 